\title{
Bread making potential of Triticum aestivum and Triticum spelta species
}

https://doi.org/10.1515/biol-2020-0004

Received December 3, 2019; accepted January 13, 2020

\begin{abstract}
The aim of this study was to assess the effect of two winter wheat species: Triticum aestivum ssp. vulgare, and Triticum spelta, cultivated in different percentage of cereals in crop rotation, on their bread making potential. The analyzed grain samples were obtained from a field experiment conducted during three years 2014-2016 at the Experimental Station in Osiny $\left(51^{\circ} 35^{\prime}, 21^{\circ} 55^{\circ}\right)$, Institute of Soil Science and Plant Cultivation, State Research Institute, Puławy, Poland. The experiment was established following different percentages of shared cereals in crop rotation (SCCR): 50, 75 and 100\%. Wheat cultivation was performed in accordance with good agricultural practice standards. Protein content, gluten content, Zeleny sedimentation index and alveograph properties were determined. Wheat species strongly influenced bread potential. The Triticum aestivum compared to Triticum spelta was characterized by significantly higher gluten qualityand Zeleny sedimentation index as well as better alveograph properties. Common wheat showed the highest baking value (W). Spelt wheat was characterized by the lowest tenacity $(\mathrm{P})$ and the highest extensibility (L). Moreover, the percentage of cereals in crop rotation had an effect on grain and dough quality parameters. Cultivation of wheat in $100 \%$ share of cereals resulted in the lowest grain and dough quality.
\end{abstract}

Keywords: alveograph, grain and dough quality, percentage of cereals in crop rotation, common wheat, spelt wheat

\footnotetext{
*Corresponding author: Edyta Aleksandrowicz, Department of Cereal Crop Production Institute of Soil Science and Plant Cultivation - State Research Institute, Puławy, 24-100, Czartoryskich 8, Poland, E-mail: e.aleksandrowicz@iung.pulawy.pl

Grażyna Podolska, Department of Cereal Crop Production Institute of Soil Science and Plant Cultivation - State Research Institute, Puławy, 24-100, Czartoryskich 8, Poland

Anna Szafrańska, Department of Grain Processing and Bakery Institute of Agricultural and Food Biotechnology, Warsaw, 02-532, Rakowiecka 36, Poland

ORCID: Grażyna Podolska 0000-0003-1782-712X; Edyta AleksandrowiCz 0000-0002-7444-5227; Anna Szafrańska 0000-0003-1038-7811
}

\section{Introduction}

Wheat is an important and extensively-used cereal in human and animal diets worldwide. Optimising grain yield and food quality are crucial for wheat crop competitiveness. Improvements may be feasible based upon the selection of adapted cultivars and adequate management practices [1]. Grain yield and seed quality of wheat are dependent on environmental conditions, genetic factors, crop management, and the interaction between these influences [2]. With regard to crop management, cropping system, dose and duration of nitrogen fertilizer application, as well as crop protection against diseases, all play an important role. In all countries, crop rotation is constantly adapted to economic conditions and political intentions. Crop rotation is especially important in agricultural cooperative farms that are aimed at growing one or two main crops. In Polish conditions, a cereal share in crop rotation equals $70 \%$. This means that cereals are grown for three consecutive years in $100 \%$ share of cereals. Wheat cultivation in such crop rotation often promotes an increase in disease, weed infestation, and a reduction in yield. An optimal crop rotation utilizes the specific ability of some species of crops to favorably influence physical, chemical and biological properties of the soil. In correct crop rotation, the share of cereal should amount to $50 \%$, with $50 \%$ dicotyledonous plants. Spelt wheat is an ancient subspecies of modern wheat that can be grown at higher elevations and under harsher climate conditions than wheat $[3,4]$. For example, spelt can be grown in mountainous areas, on light soils that are not nutrient rich. Moreover, its cultivation does not require the use of fertilizers and plant protection products, as common wheat production does [5-7]. The noticeable resistance of the grain to external factors results from the presence of the husk, which is a natural protective barrier. Glumes, which tightly cover the spelt grain, protect it against diseases, crop pests, heavy metals or pesticide residues [8, 9]. However, lower yield of spelt and difficulties occurring with harvesting due to a short and frangible ear rachis, have contributed to the marginalization of its cultivation 
in favor of the cultivation of common wheat characterized by generally higher yield [9]. Despite the above-mentioned drawbacks, the rebirth of spelt cultivation has been observed recently.

Compared to common wheat, spelt has a higher mineral and protein content [10, 11]. Additionally, this crop is characterized by a higher amount of protein, higher gluten content, and higher falling number, however, gluten quality and sedimentation index are lower. Spelt gluten has strong softening properties. The protein content of spelt grain ranges from 13.0 to $16.5 \%$ [10, 12]. The content and composition of gluten proteins are the main factors influencing its technological quality [13-16]. Gliadins and glutenins are storage proteins with the latter being more important than gliadins for obtaining good dough properties [17-19]. Both fractions are rich in glutamic acid, proline, and hydrophobic amino acids, while gliadins have a relatively low content of lysine, histidine, threonine, and tryptophan. It is thus thought that the nutritional value of gliadins and glutenins is lower than that of albumins and globulins. The quality parameters of grain are a dynamic feature and can be improved with proper agricultural engineering procedures [20]. The rheological properties of bread depend mainly on the method of wheat cultivation, with nitrogen fertilization being the most important factor influencing the content and quality of cereal grain protein $[20,21]$.

The content of albumins and globulins in spelt compared to wheat is similar, while the gliadin/glutenin ratio is larger. Common wheat cultivars contain the highest proportion of total glutenins and high molecular weight (HMW) subunits, which are known to be important for bread-making quality. Schober et al. [22] found that the gluten quality is characterized by a wide variability, and that there is an interaction between cultivars and the growing location with respect to gluten rheology, quality parameters, and the content of different protein classes. The presence of such gluten in dough has a detrimental effect on its rheological properties and on its gas trapping ability during fermentation $[9,23]$. The rheological properties of spelt flour indicate what kind of product spelt flour is best for.

On the other hand, the breeding studies as well as scientific research are aimed at obtaining new spelt cultivars that could combine both a high nutritional value and favorable technological properties more similar to common wheat. However, the literature related to the alterations in spelt flour characteristics resulting from breeding is still scarce.
Such spelt breeding programs take place in Poland and one of the new Polish winter spelt cultivars is "Rokosz". The aim of this study was to compare the quality parameters of this new spelt wheat cultivar cv. Rokosz against a highquality winter wheat, cv. Bamberka, and to determine if and how cultivation in $100 \%$ share of cereals influences the quality traits and protein fraction composition of the two types. The results revealed differences in quality parameters and protein fraction composition, important for baking and miling industry, between spelt and common wheat. Moreover, this study provides insights into improving the cultivation of common and spelt wheat to achieve higher quality raw material.

\section{Material and Methods}

\subsection{Plant materials/agronomic trials}

The analyzed grain samples were obtained from a threeyear field experiment (2014-2016) conducted at the Experimental Station in Osiny (51 $\left.{ }^{\circ} 35^{\prime}, 21^{\circ} 55^{\prime}\right)$, Institute of Soil Science and Plant Cultivation, State Research Institute, Puławy, Poland. The experiment was situated on pseudopodic soil, pH 6.76. Crop rotations with 50, 75 and $100 \%$ proportions of cereals were used. Crops in different crop rotation are presented in Table 1. Wheat cultivation was performed in accordance with good agricultural practice standards (nitrogen fertilization, sowing term and sowing density). The fertilization level was carried out by balance method taking into account the content of bioavailable forms of phosphorus and potassium and the content of mineral nitrogen in the soil. The crops were protected against weeds, diseases and pests by applying Alister Grande (active substances: diflufenican, mesosulfuron-methyl, iodosulfuron methylsodium) 1.01 ha $^{-1}$, Capallo 337 SE (active substances: fenpropimorph, epoxiconazole, metrafenone)1.5 1 ha $^{-1}+$ Fury 100EW (zetacypermethrin) 0,1l ha' ${ }^{-1}$ Medax Top 350 SC (mepiquat chloride, prohexadione calcium) 0,8 $1 \mathrm{ha}^{-1}$. Harvest was performed at full maturity phase.

Table 1. The crop rotation with 50,75 and $100 \%$ share of the cereals

\section{Crop rotation}

\begin{tabular}{lll}
\hline $\mathbf{5 0} \%$ share of cereals & $\mathbf{7 5 \%}$ share of cereals & $\mathbf{1 0 0} \%$ share of cereals \\
\hline Winter rape & Winter rape & Winter wheat \\
Winter wheat & Winter triticale & Winter triticale \\
Beans & Winter wheat & Spring barley \\
Winter triticale & Spring barley & \\
\hline
\end{tabular}




\subsection{Grain and flour quality parameters}

Gluten content, gluten index, Zeleny sedimentation index, falling number and alveograph properties were determined to assess the baking quality of the tested wheat species. A hammer mill (FN 3100, Perten Instruments, Sweden) equipped with a $0.8 \mathrm{~mm}$ sieve was used to grind each wheat sample to wholegrain flour for gluten and falling number analyses. Wet gluten content and gluten index were determined according to ICC Standard No. 155 (Glutomatic 2200, Perten Instruments, Sweden). The gluten index (GI) is a method of analysing wheat protein that provides simultaneous determination of gluten quality and quantity. The GI value expresses a weight percentage of the wet gluten remaining on sieves after automated washing in salt solution and centrifugation (Centrifuge 2015, Perten Instruments, Sweden). GI allows for a reliable prediction of bread-making quality. Zeleny sedimentation index was determined according to ISO 5529 (Shaker Brabender, Germany) and falling number according to EN ISO 3093 (Falling number 1800, Perten Instruments, Sweden). A Sedimat laboratory mill (Brabender GmbH \& Co. KG, Germany) was used to grind each sample to flour for the Zeleny sedimentation test.

\subsection{Rheological tests}

Rheological properties of dough were studied using the alveograph test (ISO 27971). Grain samples were adjusted to $16 \%$ moisture content with water. After conditioning overnight for $24 \mathrm{~h} \pm 1 \mathrm{~h}$, grain samples were milled in a Chopin-Dubois 1 laboratory mill to obtain flour for the determination of the rheological properties of dough by Chopin alveograph. Gluten extensibility (alveograph $\mathrm{L}(\mathrm{mm})$ ), tenacity (alveograph $\mathrm{P}(\mathrm{mm})$ ), baking value (alveograph $\mathrm{W}(\times 10-4 \mathrm{~J})$, tenacity/extensibility ratio (alveograph $\mathrm{P} / \mathrm{L}$ ), dough swelling index $\mathrm{G}(\mathrm{ml})$, and elasticity index Ie (\%) were determined according to the alveograph manufacturer's instructions (Chopin, France), using $220 \mathrm{~g}$ flour samples and constant water absorption (55\%) (ISO 27971).

\subsection{Protein fraction composition}

To determine the content of particular protein fractions, a 3 grain sample was ground in an IKA A10 laboratory mill (Labortechnik) in such a manner so that all particles could be sieved through a $400 \mu \mathrm{m}$ mesh sieve (ether particles smaller than $250 \mu \mathrm{m}$ accounted for $90 \%$ ). The samples were degreased with petroleum ether in Soxhlet extractors (16 hours). After evaporation of the solvent, 100 $\mathrm{mg}$ portions of powder were weighed out and placed in Eppendorf tubes, and then three protein fractions were extracted according to [24].

1. Albumins + globulins - double extraction of $1 \mathrm{~cm}^{3}$ of the mixture $\left(0.4 \mathrm{~mol} / \mathrm{L} \mathrm{NaCl}+0.067 \mathrm{~mol} / \mathrm{L} \mathrm{HKNaPO}_{4}\right.$ with a $\mathrm{pH}$ of 7.6

2. Prolamins - triple extraction of $1 \mathrm{~cm}^{3}$ of the mixture (60\% ethanol)

3. Glutelins - double extraction of $1 \mathrm{~cm}^{3}$ of the mixture (50\% propanol $1+2 \mathrm{~mol} / \mathrm{L}$ urea $0.05 \mathrm{~mol} / \mathrm{L}$ Tris- $\mathrm{HCl}(\mathrm{pH}$ 7.5) $+1 \%$ DTE under nitrogen.

The first two protein fractions were extracted at room temperature using an Eppendorf thermomixer (10minute extraction). Glutelins were extracted at $60^{\circ} \mathrm{C}$ in the thermomixer. After each extraction, the mixture was centrifuged at $11000 \mathrm{x}$ g. The collected fractions were lyophilized and then dissolved in $2 \mathrm{~cm}^{3}$ of the respective phase (1-3), cleaned through a Spartan - 3NY filter with a $0.45 \mu \mathrm{m}$ mesh and transferred to glass vials. The determinations were made using a Hewlett Packard Series 1050 system with the following parameters: column RP-18 Vydac 218TPP54, $5 \mu \mathrm{m}, 250$ x $4.6 \mathrm{~mm}$, pre-column Zorbax 3000 SB-C18 $4.6 \times 12.5 \mathrm{~mm}$, column temperature $45^{\circ} \mathrm{C}$, mobile phase flow rate $1 \mathrm{ml}$ per min, injection size of 20 $\mu$. The separation was performed using a two-component gradient. The proportion of component A: $0 \min 75 \%, 5$ $\min$ 65\%, $10 \min 50 \%, 17 \min$ 25\%, $18 \min$ 15\%, $19 \min$ $75 \%$. The first gradient (A) was water with an addition of $0.1 \%$ TFA, while the second gradient (B) was ACN with an addition of $0.1 \%$ TFA. The detection was carried out using a detector manufactured by the same company, and the reading was done at a wavelength of $210 \mathrm{~nm}$. The results were analyzed using HPLC 3D ChemStation software (Hewlett Packard).

\subsection{Statistical analysis}

Analyses of all parameters were performed in four replications. The data was computed by multi-way analysis of variance (ANOVA) and the least significant difference (LSD) multiple range test was used at the $0.05 \%$ level. STATISTICA 6.1 (StatSoft Inc., Tulsa, USA) software was used. 


\section{Results and discussion}

\subsection{Factors influencing quality parameters}

The results of the analysis of variance showed that almost all the factors had a significant effect on the different traits. Species was the most important factor explaining the variation, followed by share of cereals in crop rotation (SCCR) and G $\times$ SCCR interaction. Wheat species had a significant impact on most of the tested traits, except tenacity/extensibility ratio (alveograph $\mathrm{P} / \mathrm{L}$ ) and $\mathrm{G}$ (alveograph value). The share of cereals in crop rotation significantly influenced sedimentation index, falling number, baking value (alveograph $\mathrm{W}$ ), extensibility (alveograph L), dough swelling index (alveograph G) and elasticity index (alveograph Ie). We also found interaction between cereals in crop rotation and species in gluten index, sedimentation index, strength, extensibility, tenacity/extensibility ratio (Table 2-6). The importance of crop rotation on the grain quality of wheat was confirmed by Babulicová et al. [25]. The authors found that in crop rotation with less share of cereals, the wet gluten content and gluten index were statistically higher than in crop rotation with a higher share of cereals. They also found that falling number and sedimentation index was not affected by the share of cereals in crop rotation.

Table 2. The influence of Triticum species and share of cereals on wet gluten content and gluten index (analysis of variance)

\begin{tabular}{lcccccccc}
\hline Factor & \multicolumn{4}{c}{ Wet gluten content (\%) } & \multicolumn{3}{c}{ Gluten index } \\
\cline { 2 - 9 } & $D f$ & $M S$ & $F$ & $P$-value & $D f$ & MS & $F$ & $P$-value \\
\hline T. species & 1 & 1158.8 & 161.0 & $\star \star \star \star$ & 1 & 62157.8 & 744.5 & $\star \star \star \star$ \\
SCCR & 2 & 14.09 & 1.96 & ns & 2 & 1.056 & 1.056 & $\mathrm{~ns}$ \\
AxB & 2 & 4.828 & 0.67 & ns & 2 & 323.6 & 3.876 & $\star$
\end{tabular}

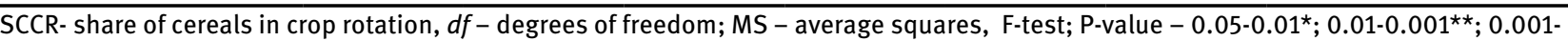
$0.0001^{\star \star \star},>0.0001^{\star \star \star \star}$, ns - not significant.

Table 3. The influence of Triticum species and share of cereals on sedimentation index and falling number (analysis of variance)

\begin{tabular}{lcccccccc}
\hline Factor & \multicolumn{3}{c}{ Sedimentation index $(\mathrm{ml})$} & \multicolumn{3}{c}{ Falling number (s) } \\
\cline { 2 - 9 } & $D f$ & $M S$ & $F$ & $P$-value & $D f$ & MS & $F$ & $P$-value \\
\hline T. species & 1 & 4648.9 & 152.6 & $\star \star \star \star$ & 1 & 12173.4 & 13.91 & $\star \star \star$ \\
SCCR & 2 & 185.9 & 6.104 & $\star \star \star *$ & 2 & 13479.8 & 15.41 & $\star \star \star \star$ \\
AxB & 2 & 293.3 & 9.629 & $\star \star \star \star *$ & 2 & 568.54 & 0.650 & $\mathrm{~ns}$ \\
\hline
\end{tabular}

Table 4. The influence of Triticum species and share of cereals on alveograph baking value $(\mathrm{W})$ and tenacity $(\mathrm{P})$ (analysis of variance)

\begin{tabular}{|c|c|c|c|c|c|c|c|c|}
\hline \multirow[t]{2}{*}{ Factor } & \multicolumn{4}{|c|}{ Baking value (W) } & \multicolumn{4}{|c|}{ Tenacity (P) } \\
\hline & $D f$ & MS & $F$ & $P$-value & $d f$ & $M S$ & $F$ & $P$-value \\
\hline T. species & 1 & 491040.5 & 680.7 & $\star \star \star \star$ & 1 & 54010.8 & 563.6 & $\star \star \star \star ~$ \\
\hline SCCR & 2 & 9146.6 & 12.68 & $\star \star \star \star ~$ & 2 & 255.12 & 2.662 & ns \\
\hline$A \times B$ & 2 & 43335.3 & 6.010 & * & 2 & 190.84 & 1.991 & ns \\
\hline
\end{tabular}

Table 5. The influence of Triticum species and share of cereals on alveograph extensibility (L) and tenacity/extensibility ratio (P/L) (analysis of variance)

\begin{tabular}{|c|c|c|c|c|c|c|c|c|}
\hline \multirow[t]{2}{*}{ Factor } & \multicolumn{4}{|c|}{ Gluten extensibility (L) } & \multicolumn{4}{|c|}{ Tenacity/extensibility ratio (P/L) } \\
\hline & $D f$ & MS & $F$ & $P$-value & $d f$ & $M S$ & $F$ & $P$-value \\
\hline T. species & 1 & 1615.0 & 41.95 & 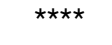 & 1 & 11.14 & 430.6 & ns \\
\hline SCCR & 2 & 1272.0 & 33.04 & 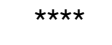 & 2 & 0.348 & 13.44 & ns \\
\hline$A \times B$ & 2 & 295.6 & 7.679 & $\star \star$ & 2 & 0.149 & 5.743 & ** \\
\hline
\end{tabular}


Table 6. The influence of Triticum species and share of cereals on alveograph dough swelling index (G) and elasticity index (le) (analysis of variance)

\begin{tabular}{lcccccccc}
\hline Factor & \multicolumn{4}{c}{ Dough swelling index (G) } & \multicolumn{3}{c}{ Elasticity Index (le) } \\
\cline { 2 - 10 } & $D f$ & $M S$ & $F$ & $P$-value & $d f$ & MS & $F$ & $P$-value \\
\hline T. species & 1 & 0.957 & 0.291 & ns & 1 & 2346.1 & 664.3 & $\star \star \star \star$ \\
SCCR & 2 & 27.57 & 8.402 & $\star \star \star \star$ & 2 & 52.04 & 14.73 & $\star \star \star \star$ \\
AxB & 2 & 5.816 & 1.772 & ns & 2 & 1.791 & 0.507 & $\mathrm{~ns}$ \\
\hline
\end{tabular}

\subsection{Baking properties of tested wheat grain}

The two tested species differed with respect to many quality traits. Triticum spelta had higher gluten content, falling number, and alveograph extensibility (L value) compared with Triticum aestivum, but lower gluten index, sedimentation value, and alveograph parameters such as: $\mathrm{W}, \mathrm{P}, \mathrm{P} / \mathrm{L}$ ratio and Ie value (Table 7 ). The differences between Triticum aestivum and Triticum spelta in gluten content have been confirmed in a number of previous studies [26-29]. According to Rachon et al. [29], the differences between gluten content for spring spelt cv. Blauer Samtiger and spring wheat cv. Parabola equaled $8.9 \%$. We found the difference to be $5.6 \%$. Majewska et al. [30], showed that flours of spelt wheat cultivars such as: Ceralio, Schwabenkorn, Frankenkorn, Holstenkorn,
Schwabenspelz, Ostro and Oberkulmer Rothkorn, were characterized by significantly higher wet gluten content (interval 27.3-45.6\%) comparing to common wheat flour cv. Korweta (22.5\%). Our study is in agreement with those findings; the differences between Bamberka and Rokosz cv. equaled $5.6 \%$. When comparing our results to those described in the literature, we notice that cv. Rokosz was characterized by similar wet gluten content to the German spelt wheat cultivars (Schweizer, Altgold, Zeinnars, Weisser, Bastard, Burgdorf, Oberlander) in which the gluten content was in the range of $31-37 \%$ [31]. Furthermore, the research conducted by Krochmal-Marczak and Sawicka [32], showed that wet gluten content in spelt wheat (Frankencorn, Ceralio and Schwabencorn) was lower (in range of $23.5-27.5 \%$ ). The wet gluten content was not influenced by the share of cereals in crop rotation or by the interaction between wheat

Table 7. Qualitative features depending on wheat species (average for the three years and SCCR)

\begin{tabular}{|c|c|c|c|}
\hline \multirow[t]{2}{*}{ Features } & \multicolumn{2}{|l|}{ Triticum species } & \multirow[t]{2}{*}{ LSD } \\
\hline & $\begin{array}{l}\text { Triticum aestivum } \\
\text { cv. Bamberka }\end{array}$ & $\begin{array}{l}\text { Triticum spelta } \\
\text { cv. Rokosz }\end{array}$ & \\
\hline Gluten content (Nx5.7) (\% d.b) & 29.5 & 35.1 & $\star \star \star \star$ \\
\hline Gluten index & 76.9 & 35.4 & $\star \star \star \star *$ \\
\hline Zeleny sedimentation index (ml) & 41.1 & 29.7 & $\star \star \star \star ~$ \\
\hline \multicolumn{4}{|l|}{ Alveograph parameters } \\
\hline$W\left(\times 10^{-4} \mathrm{~J}\right)$ & 312 & 146 & $\star \star \star \star$ \\
\hline$P(m m)$ & 118 & 62 & $\star \star \star \star ~$ \\
\hline $\mathrm{L}(\mathrm{mm})$ & 79 & 88 & $\star \star \star \star ~$ \\
\hline$P / L$ & 1.53 & 0.71 & $\star \star \star \star$ \\
\hline $\mathrm{G}(\mathrm{ml})$ & 19.7 & 20.8 & ns \\
\hline & \multicolumn{3}{|c|}{ Protein fraction (mAU x s) } \\
\hline albumins+globulin & 16602.5 & 16130.5 & * \\
\hline$\omega$-gliadin & 2310.0 & 1978.7 & * \\
\hline$\alpha / \beta$-gliadin & 16995.2 & 15820.7 & * \\
\hline Y-gliadin & 11860.0 & 11253.0 & * \\
\hline HMW-glutenin & 8108.250 & 10265.2 & * \\
\hline LMW-glutenin & 20995.7 & 23574.7 & * \\
\hline
\end{tabular}

HMW- glutenin - high molecular weight glutenin subunit

LMW-glutenin- low molecular weight glutenin subunit 
species and percentage of cereals in crop rotation (Table 2). Our results are in contrast to results obtained by Babulicova and Gavurnicova [25]. They concluded that significantly higher wet gluten content was found in crop rotation with $60 \%$ share of cereals, compared with crop rotation with $80 \%$ share of cereals. Additionaly, according to Rachon et al. [29], the wet gluten content is influenced by the level of inputs.

According to Capouchová [10] the gluten of spelt wheat has lower quality than the gluten of the common wheat, which is in agreement with our study. For baking purposes, wheat with a gluten index of $60-90 \%$ is most desirable. Wheat with an index of less than 50 is more difficult to process; the dough is sticky, and is mainly suitable for biscuits with an additional potential application in twolayer flat breads [33]. Common wheat cv. Bamberka was characterized by a significantly higher average gluten index (76.9) over the three years, compared to Rokosz cv. (35.4) (Table 7). The previous study [12] showed a large variability in gluten index from 10.2 to $34.2 \%$. The ideal gluten index of $60-90 \%$ was not achieved by spelt in any crop rotation. However, we found an interaction in gluten index between crop rotation and wheat species (Figure 1). In cv. Rokosz, the lowest gluten index was in the $75 \%$ share of cereals compared with 50 and $100 \%$. In $\mathrm{cv}$. Bamberka on the other hand, the lowest gluten index was in the $100 \%$ share of cereals compared with $50 \%$ and $75 \%$. Our results are in agreement with Babulicova and Gavurnicova [25]. Additionaly, one more study [34] reports that nitrogen fertilization had an important role in the gluten index value of spelt wheat.

The sedimentation index characterizes the viscoelastic features and quality of the proteins and it indicates the potential for the fermentation process in the dough. When comparing yearly averages, significantly higher values were found in the common wheat cv. Bamberka (41.1 ml), followed by cv. Rokosz (29.7 ml) (Table 7). The results agree with those obtained by other researchers [3, $12,29]$ according to which the sedimentation index in the spelt wheat grain was lower than in the common wheat grain. The sedimentation index was also influenced by the share of cereals in crop rotation and the interaction between wheat species and crop rotation (Figure 2). In cv. Bamberka, the lowest value of sedimentation index was in the $100 \%$ share of cereals, but in cv. Rokosz, the highest sedimentation index was in the $100 \%$ share of cereals. Similar results were achieved by Babulicova and Gavurnicova [25], and López-Bellido et al. [35].

The falling number test is used to evaluate the amount of sprout damage and gives an indication of alphaamylase activity in grains. We found that Triticum spelta had the highest falling number value compared with common wheat (Table 7). This is in agreement with other studies [12]. Available literature indicates a large variation in the value of the falling number in spelt varieties. According to Rachon [29], falling number values ranged from 228 (Ceralio variety) to 354 (Holstenkorn variety). However, according to Makowska et al. [31], the values of falling numbers ranged from 150 (variety Oberlander) to 228 (Bastard variety). The share of cereals in crop rotation significantly influenced the falling number. In both studied species, the highest falling number was in the $100 \%$ share of cereals in crop rotation but the lowest after winter rape in the $50 \%$ of cereals in crop rotation. Babulicova and Gavurnicova [24] did not find differences between falling number and crop rotation.

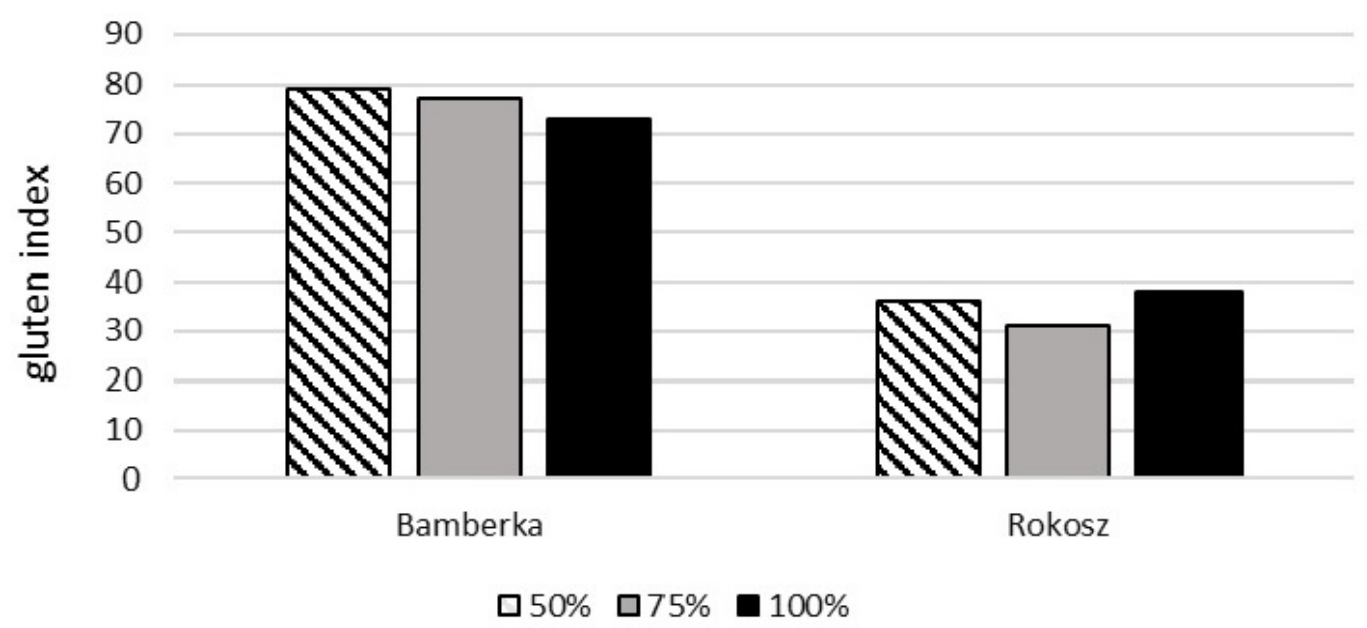

Figure 1. Interaction between the wheat species and share of cereals in crop rotation in gluten index 


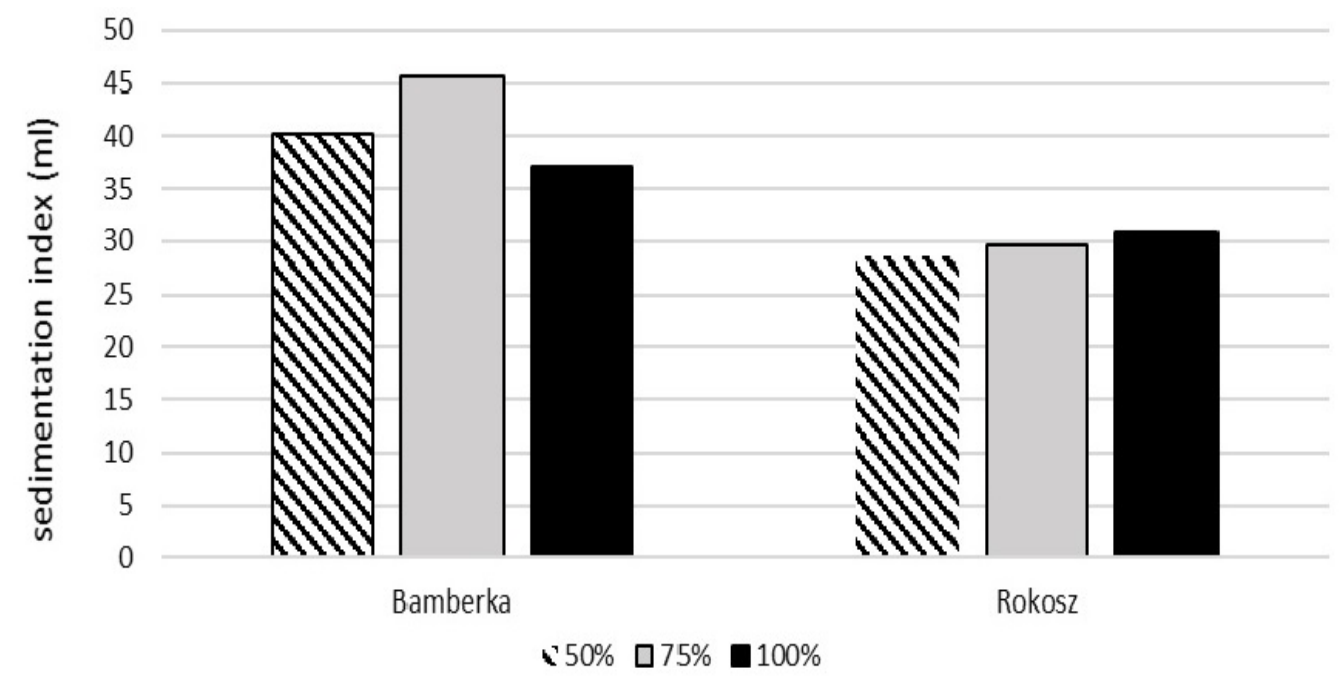

Figure 2. Interaction between the wheat species and share of cereals in crop rotation in sedimentation index

\subsection{Rheological properties of dough}

The rheological properties of spelt dough and wheat dough were assessed using an alveograph. Rheological features of dough are a function of the properties of flour's components and their mutual interactions occurring as a result of hydration and energy supply during kneading. It is known that starch, gluten, pentosans and fat play a crucial role in forming wheat dough [36]. The analyzed wheat doughs differed in "W" value. Alveograph baking value (W), an indicator of baking quality, in tested wheat flour samples ranged from 69 to $420 \times 10^{-4} \mathrm{~J}$ which according to Abramczyk and Stępniewska [37] indicates its wide technological suitability. Good quality wheat and improving wheat should be characterized by "W" values in the range $220-300 \times 10^{-4} \mathrm{~J}$ and higher than $300 \times 10$ 4 J, respectively, whilst confectionary wheat should be characterized by "W" values in the range of 160 to $200 \times 10$. ${ }^{4} \mathrm{~J}$ [37]. In our study, the Bamberka was characterized by a good "W" value ( $\left.312 \times 10^{-4} \mathrm{~J}\right)$, but Rokosz by the lowest baking value "W" $\left(146 \times 10^{-4} \mathrm{~J}\right)$, which informs the potential user of grains about the lower quality of gluten complex and its suitability for production of, for example, waffles (Table 7). This results are confirmed by Sobczyk et al. [39]. Spelt wheat dough energy of 10 cultivars was lower compared to common wheat. They found differences between cultivars. The largest energy $\left(71 \mathrm{~cm}^{2}\right)$ was found for the dough of Schwabenkorn cv flour, while the smallest for the STH 8 line $\left(24 \mathrm{~cm}^{2}\right)$ and the Ostro $\mathrm{cv}\left(25 \mathrm{~cm}^{2}\right)$. Grobelnik Mlakar et al. [40] reported similar values of this parameter $\left(35-36 \mathrm{~cm}^{2}\right)$ for the spelt dough. The tested spelt flours can be regarded as weak, according to the classification given by Boyacioglu and D’Appolonia [41].
Alveograph parameter (P), is considered as an indicator of the dough's tenacity and is dependent on the viscosity of dough and a measure of the absorption capacity of flours. The highest alveograph tenacity $(\mathrm{P})$ was detected for wheat variety Bamberka (118 $\mathrm{mm})$, the lowest for $\mathrm{cv}$. Rokosz (62 mm) (Table 7). Krawczyk et al. [9] assessing the Polish spelt genotypes showed that the values of this feature were very diverse and ranged from $54 \mathrm{~mm}$ (STH 12) to $218 \mathrm{~mm}$ (STH 11). Lower values of this parameter in spelt wheat were confirmed by Sobczyk et al. [38]. Alveograph parameter (L), which is related to dough extensibility and predicts the handling properties of the dough in the tested wheat samples, was in the range of 24 to $135 \mathrm{~mm}$ [38]. The highest extensibility was demostrated by Triticum spelta $(88 \mathrm{~mm})$ compared with common wheat $(79 \mathrm{~mm})$ (Table 7). Similar results were obtained by Sobczyk et al. [39]. They found that spelt doughs showed a lower resistance to extensibility compared to the wheat dough. The P/L index is a commonly used parameter in the wheat trade where a value of 0.50 indicates either resistant and very extensible dough or moderately extensible less resistant dough. The $\mathrm{P} / \mathrm{L}$ value for Bamberka was 1.53, and for Rokosz 0.71 (Table 7). The value of 1.50 indicates very strong and moderately extensible dough, whilst raw material with a $\mathrm{P} / \mathrm{L}$ value in the range of 0.40 to 0.80 is suitable for bakery production. Wheat suitable for confectionery products should exhibit aP/L value lower than 0.50 [38]. Dough obtained from cv. Rokosz was characterized by high tenacity and low extensibility ( $\mathrm{P} / \mathrm{L}$ index above 1.0).

The share of cereals in crop rotation had an important influence on the parameters: "W", "L", "G" and "Ie". (Table 8). In both cultivars the "W" parameter was the highest in $50 \%$ of cereals in crop rotation but the smallest 
Table 8. Qualitative features of cv. Bamberka and cv. Rokosz depending on share of cereal in crop rotation (average for years)

\begin{tabular}{|c|c|c|c|c|c|c|}
\hline \multirow[t]{4}{*}{ Features } & \multicolumn{6}{|c|}{ Triticum species } \\
\hline & \multicolumn{3}{|c|}{ Triticum aestivum cv. Bamberka } & \multicolumn{3}{|c|}{ Triticum spelta cv. Rokosz } \\
\hline & \multicolumn{6}{|c|}{ Share of cereals in crop rotation } \\
\hline & $50 \%$ & $75 \%$ & $100 \%$ & $50 \%$ & $75 \%$ & $100 \%$ \\
\hline Gluten content (Nx5.7) (\% d.b.) & 29.5 & 30.3 & 28.7 & 34.7 & 35.6 & 35.1 \\
\hline Gluten index & 79 & 78 & 74 & 36 & 32 & 38 \\
\hline Zeleny sedimentation index (ml) & 40 & 46 & 37 & 29 & 30 & 31 \\
\hline Falling number (s) & 296 & 319 & 323 & 310 & 332 & 349 \\
\hline \multicolumn{7}{|l|}{ Alveograph parameters } \\
\hline$W\left(\times 10^{-4} \mathrm{~J}\right)$ & 318 & 343 & 275 & 153 & 146 & 140 \\
\hline$P(m m)$ & 1120 & 118 & 116 & 66 & 58 & 61 \\
\hline $\mathrm{L}(\mathrm{mm})$ & 78. & 89 & 70 & 84 & 96 & 86 \\
\hline $\mathrm{P} / \mathrm{L}$ & 1.56 & 1.35 & 1.67 & 0.79 & 0.61 & 0.72 \\
\hline $\mathrm{G}(\mathrm{ml})$ & 19.6 & 20.9 & 18.5 & 153 & 146 & 140 \\
\hline le (\%) & 54 & 55.7 & 51 & 66 & 58 & 61 \\
\hline
\end{tabular}

when wheat was grown in $100 \%$ share of cereals . In the available literature, there are few studies on the influence of agrotechnical factors on alveographic features in spelt wheat. Podolska et al. [34] showed that the baking value "W increased with anincrease in nitrogen dose. Similarly, the "P" value and "Ie" value increased with the applied dose of nitrogen from 37 to $45 \mathrm{~mm}$ and from 44.4 to 46.7 (\%), respectively and was highest at the highest dose of nitrogen.

\subsection{Protein fraction composition}

In the current study, we found that the spelt wheat protein fractions had different compositions compared with common wheat. We detected larger fractions of albumins and globulins in Triticum aestivum compared with Triticum spelta. In common wheat, the total protein content equaled $21.6 \%$, versus $20.4 \%$ in spelt wheat The smallest sub-fraction of gliadins was $\omega$-gliadins, which ranged from $2.5 \%$ of total protein content in spelt wheat, to $3.0 \%$ in common wheat. The largest sub-fraction was $\alpha / \beta$-gliadin, comprising $20.0 \%$ of total protein in spelt wheat, to $22.1 \%$ in common wheat. The $y$-gliadin content ranged from $14.2 \%$ of total protein (spelt wheat) to $15.4 \%$ (common wheat)(Fig. 3). Research conducted by MikosSzymańska and Podolska [42] does not confirm these results. These authors reported that spelt wheat contained higher amounts of $\alpha / \beta$ gliadin and $\gamma$-gliadin compared to common wheat.

Slightly different gliadin contents in common wheat were reported by Konopka et al. [33], who detected $2 \%$ fewer $\omega$-gliadins, $7 \%$ fewer $\alpha / \beta$-gliadins and $2 \%$ fewer $y$-gliadin compared with our results. According to the data

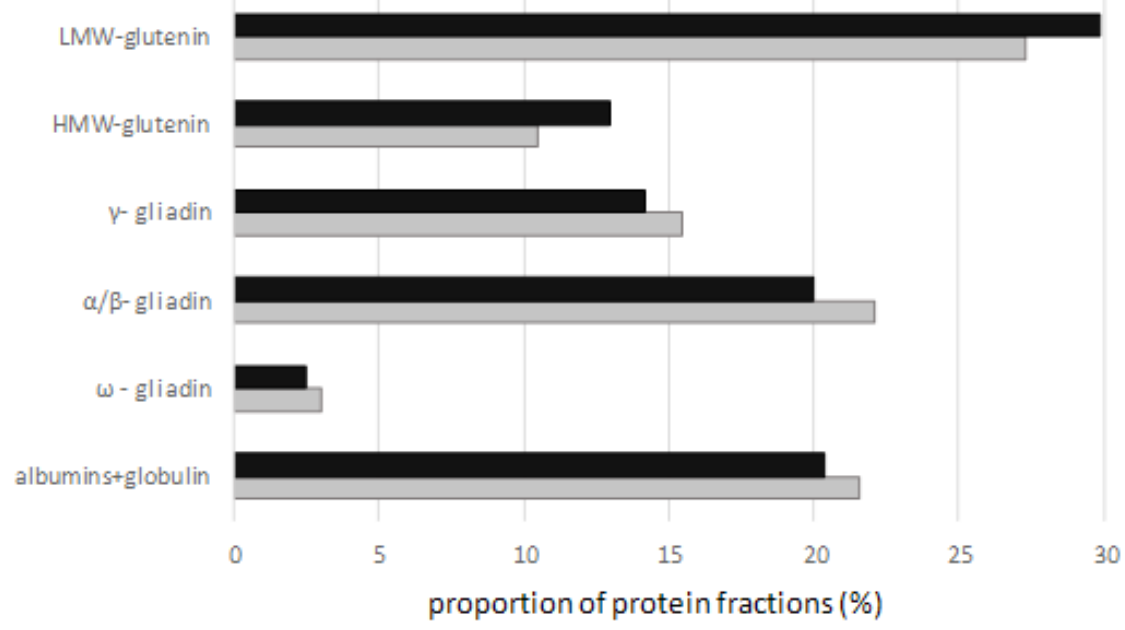

Figure 3. Proportion (\%) of protein fractions in spelt and common wheat grains (protein $=100 \%$ ) 
in Table 7 and Figure 3, glutenins comprised $37.8 \%$ of total protein content (common wheat) to $42 \%$ (spelt wheat). The baking value of flour is favorably influenced by an increase in the content of high molecular weight glutenin subunit (HMW-GS) and its ratio to low molecular weight glutenin subunit (LMW-GS) [42]. In our study the HMW-GS to LMW-GS ratio ranged from 0.38 (common wheat) to 0.40 (spelt wheat). Similar results for HMW-GS to LMW-GS ratio were obtained by Mikos-Szymańska and Podolska [42]. In spelt wheat this ratio was in the range of 0.40 to 0.45 , compareed to 0.38 in common wheat [42].

Studies published by Stepien and Wojtkowiak [44] indicate that $\alpha / \beta$-gliadins were the quantitatively predominant fraction of gliadin proteins in the grains of the examined wheat cultivars. This similarly indicated that the wheat cultivars differ from each other in the content of protein fractions. High molecular weight (HMW) and low molecular weight (LMW) subunits of glutenins are associated with dough energy and bread baking quality $[15,17]$. The number of glutenin subunits is positively correlated with the dough energy and volume of bread, whereas the content of gliadins and a higher gliadin:glutenin ratio have a negative impact on these parameters [13, 17, 45, 46].

Despite the content of HMW proteins being lower in the grain of the examined cultivars, according to [17] they determine the properties of dough to a higher degree than do LMW proteins. Also, high temperature stress, drought, excess or deficiency of nutrients can affect the protein fraction. The studies by Stepien and Wojtkowiak [44] indicate that agrotechnical factors such as nitrogen fertilization and crop rotation have significant influence on HMW and LMW glutenins. Also Tóth et. al [47], found that low nitrogen and phosphorus treatments caused an increase in the gliadin and decrease in the glutenin fractions (HMW and LMW glutenins). Geisslitz et al [48] have shown that the ratio of gliadins and glutenins was influenced by the growing location, environmental conditions (temperature) and amount and time of fertilization, but Konopka et al. [33], found that the concentration of $y$-gliadins and HMW and LMW glutenins decreased in the case of water deficit.

\section{Conclusions}

It was found that wheat species influenced the bread potential more than did the percentage of cereals in crop rotation. Wheat species strongly influenced the bread potential of the investigated crop species. The Triticum aestivum cv. Bamberka was characterized by significantly higher gluten quality, Zeleny sedimentation index, tenacity (P), and baking value (W), compared to Triticum spelta cv. Rokosz. The Triticum spelta compared with common wheat was characterized by higher gluten content, falling number, and elasticity "L".

The results suggest the suitability of cv. Bamberka for production of hamburger rolls, pizza dough and frozen dough, and the suitability of cv Rokosz for production of waffles.

The higher gliadin:glutenin ratio in spelt wheat compared with common wheat is likely the principal reason for the lower baking value of the spelt flour. In order to fully elucidate the variation in baking quality of Triticum aestivum and Triticum spelta, it would be ideal to determine the alleles of the genes coding for those proteins.

Conflict of interest: Authors state no conflict of interest.

\section{References}

[1] Silva RR, Benin G, Almeida JL, Batista Fonseca IC, Zucareli C. Grain yield and baking quality of wheat under different sowing dates. Acta Sci Agronomy. 2014;36(2):201-210.

[2] Coventry DR, Gupta RK, Poswal RS, Chhokar R S, Sharma RK, Yadav VK, et al. Wheat quality and productivity as affected by varieties and sowing time in Haryana, India. Field Crops Res 2011;123 (3):214-225.

[3] Bonafaccia G, Galli V, Francisci, R, Mairi V, Skarabanja V, Kreft I. Characteristics of spelt wheat products and nutritional value of spelt wheat-based bread. Food Chem. 2000;68:437-441.

[4] Pospišil A, Pospišil M, Svečnjak Z, Matotan S. Influence of crop management upon the agronomic traits of spelt (Triticum spelta L.) Plant Soil Environ. 2011;57(9):435-440.

[5] Kohajdova Z, Karovicova J. Nutritional value and baking applications of spelt wheat. Acta Sci.Pol. Technol. Aliment. 2008;7 (3):5-14.

[6] Wilson JD, Bechtel DB, Wilson GWT, Seib PA. Bread quality of spelt wheat and its starch. Cereal Chem. 2008;85 (5), 629-638.

[7] Zielinski H, Ceglinska A, Michalska A. Bioactive compounds in spelt bread. Euro. Food Res. Technol. 2008;226, 537-544.

[8] Radomski G, Bac A, Mierzejewska S. A comparative assessment of baking value of wheat flour and spelt. Agric. Eng. 2007;93 (5), 369-374 (in Polish).

[9] Krawczyk P, Ceglińska A, Izdebska K. Comparing rheological properties of dough and quality of bread made of spelt and common wheat flours. Żywność. Nauka. Technologia. Jakość. 2008;4 (59), 141 - 151 (in Polish).

[10] Capouchová I. Technological quality of spelt (Triticum spelta L.) from ecological growing system. Scientia Agriculturae Bohemica. 2001;32:307-322.

[11] Suchowilska E, Wiwart M, Kandler W, Krska R. A comparison of macro- and microelement concentrations in the whole grain of four Triticum species. Plant Soil Environ. 2012;58:141-147. 
[12] Mikos M, Podolska G. Bread-making quality of old common bread (Triticum aestivum ssp. vulgare L.) and spelt (Triticum aestivum ssp. spelta L.) wheat cultivars. Journal of Food, Agriculture and Environment. 2012;10 (3-4): 221-224.

[13] Uthayakumaran S, Stoddard FL, Gras PW, Bekes F. Effects of incorporated glutenins on functional properties of wheat dough. Cereal Chem. 2000;7:737-743. doi.org/10.1094/ CCHEM.2000.77.6.737

[14] Zhu J, Khan K. Quantitative variation of HMW glutenin subunits from hard red spring wheats grown in different environments. Cereal Chem. 2002;79: 783-786. DOI:10.1094/ CCHEM.2002.79.6.783

[15] He ZH, Liu L, Xia XC, Liu JJ, Peña RJ. Composition of HMW and LMW glutenin subunits and their effects on dough properties, pan bread, and noodle quality of Chinese bread wheat. Cereal Chem. 2005;82: 345-350. doi.org/10.1094/CC-82-0345

[16] Anjum FM, Khan MR, Din A, Saeed M, Pasha I, Arshad MU. Wheat gluten: high molecular weight glutenin subunits structure, genetics, and relation to dough elasticity. J Food Sci. 2007;72(3):56-63. DOI:10.1111/j.1750-3841.2007.00292.x

[17] Wieser H, Kieffer R. Correlations of the amount of gluten protein types to the technological properties of wheat flours determined on a micro-scale. J Cereal Sci. 2001;34:19-27. doi. org/10.1006/jcrs.2000.0385

[18] Zhang P, He Z, Chen D, Zhanga Y, Larroquee OR, Xia $X$. Contribution of common wheat protein fractions to dough properties and quality of northern-style Chinese steamed bread. J Cereal Sci. 2007;46: 1-10. DOI: 10.1016/j. jcs.2006.10.007

[19] Li YQ, Zhu RJ, Tian JC. Influence of wheat protein contents and fractions on dough rheological properties as determined by using a reconstitution method. Agric Sci China. 2008;7: 395-404.

[20] Labuschagne MT, Meintjes G, Groenewald FPC. The influence of different nitrogen treatments on the size distribution of protein fractions in hard and soft wheat. J Cereal Sci.2006; 43:315-321. DOI: 10.1016/j.jcs.2005.11.004

[21] Johansson E, Prieto-Linde ML, Svensson G. Influence of nitrogen application rate and timing on grain protein composition and gluten strength in Swedish wheat cultivars. J Plant Nutr. Soil Sci. 2004;167:345-350. DOI:10.1002/ jpln.200320332

[22] Schober TJ, Beana SR, Kuhn M. Gluten proteins from spelt (Triticum aestivum ssp. spelta) cultivars: a rheological and size-exclusion high-performance liquid chromatography study. Journal of Cereal Sci. 2006;44:161-173.

[23] Marconi E, Carcea M, Schiavone M, Cubadda R. Spelt (Triticum spelta L.) pasta quality: combined effect of flour properties and drying conditions. Cereal Chem. 2002;79, 634-639.

[24] Wieser H, Antes S, Seilmeier. Quantitative determination of gluten protein types in wheat flour by reversed phase high-performance liquid chromatography. Cearal Chem.1998;75:644-650

[25] Babulicová M, Gavurníková S. The influence of cereal share in crop rotations on the grain yield and quality of winter wheat. Agriculture (Pol'nohospodárstvo), 2015;61(1):12-21.DOI: 10.1515/agri-2015-0006.

[26] Chrenková M, Čerešňáková, Z, Sommer A, Gálová Z Král’ová V. Assessment of nutritional value in spelt (Triticum spelta L.) and winter wheat (Triticum aestivum L.) by chemical and biological methods. Czech Journal of Animal Science. 2000;45:133-137.

[27] Lacko-Bartošova $M$, Rédlová $M$. The significance of spelt wheat cultivated in ecological farming in the Slovak Republic. Conference proceedings. Organic farming. 2007;79-81.

[28] Jablonskytė-Raščè D, Maikštènienė S, Mankevičienė A. Evaluation of productivity and quality of common wheat (Triticum aestivum L.) and spelt (Triticum spelta L.) in relation to nutrition conditions Zemdirbyste-Agriculture, 2013;100(1):45-56. DOI:10.13080/z-a.2013.100.007

[29] Rachoń L, Szumiło G, Szafrańska A, Kotyrba D. Bread-making potential of selected spring wheat species depending on crop year and production technology intensity Zemdirbyste-Agriculture. 2016;103(4):369-376. DOI 10.13080/ z-a.2016.103.047

[30] Majewska K, Dąbkowska, E, Żuk-Gołaszewska K, Tyburski J. Wartość wypiekowa mąki otrzymanej z ziarna wybranych odmian orkiszu (Triticum spelta L.). Żywność. Nauka. Technologia. Jakość. 2007;2(51):60-71.

[31] Makowska A, Obuchowski W, Adler A, Sulewska H. Milling and breadmaking properties of some spelt varieties. Fragm. Agronom. 2008; 1 (97):228-239 (in Polish).

[32] Krochmal-Marczak B, Sawicka B. Bread making value of spelt wheat varieties (Triticum aestivum ssp. spelta) cultivated in South-East part of Poland. Conference proceedings, Hodowla uprawa i wykorzystanie pszenicy orkisz w warunkach zmian klimatu. 2011;16-17 (in Polish).

[33] Konopka I, Tańska M, Pszczółkowska A, Fordoński G, Kozirok W, Olszewski J. The effect of water stress on wheat kernel size, color and protein composition. Pol J Nat Sc. 2007;22 (2):157-171. DOI 2478/v10020-007-0016-5

[34] Podolska G, Rotkaehl J, Górniak W, Stępniewska S. Effect of nitrogen levels and sowing density on the yield and baking quality of spelt wheat (Triticum aestivum. ssp. spelta) cv. Rokosz. Annales UMCS Sectio E LXX. 2015;(1):93-103 (in Polish).

[35] López-Bellido L. López-Bellido R J. Castillo JE, López-Bellido FJ. Effects of long-term tillage, crop rotation and nitrogen fertilization on bread-making quality of hard red spring wheat. Field Crop Res. 2001;72:197-210. doi.org/10.1016/ S0378-4290(01)00177-0

[36] Hung VP, Maeda T, Morita N. Waxy and high-amylose wheat starches and flours - characteristics, functionality and application. Trends Food Sci. Tech. 2006; 17 (5), 448-456. DOI: 10.1016/j.tifs.2005.12.006

[37] Abramczyk D, Stępniewska S. Requirements of alveograph properties of wheat flour for various products (in Polish). Proceedings of the XXIX Conference in Krynica Morska, May 27-30th. , Poland. 2009:22-24 (in Polish).

[38] Dapčević Hadnađev T, Pojić M, Hadnađev M, Torbica A. The role of empirical Rheology in Flour Quality Control, Wide Spectra of Quality Control, Akyar I. (Ed.), InTech. 2011; DOI:10.5772/24148.

[39] Sobczyk A, Pycia K, Stankowski S, Jaworska G, Kuzniar P. Evaluation of the rheological properties of dough and quality of bread made with the flour obtained from old cultivars and modern breeding lines of spelt (Triticum aestivum ssp. spelta). J Cereal Sc. 2017; 77:35-41. dx.doi.org/10.1016/j. jcs.2017.07.013 
[40] Grobelnik Mlakar S, Bavec M, Turinek M, Bavec,F. Rheological properties of dough made from grain amaranth-cereal composite flours based on wheat and spelt. Czech J. Food Sci 2009; 27 (5), 309-319.

[41] Boyacioglu MH, D’Appolonia, BL. Characterization and utilization of durum wheat for breadmaking. Comparison of chemical, rheological and baking properties between bread wheat flours and durum wheat flours. Cereal Chem. 1994;71: 21-28.

[42] Mikos-Szymanska M, Podolska G. The effect of sowing date and seeding rate on spelt and common wheat protein composition and characteristics. Quality Assurance and Safety of Crops\&Foods. 2015;8(2):289-300. doi.org/10.3920/ QAS2014.0574

[43] Daniel C, Triboi E. Changes in wheat protein aggregation during grain development: effects of temperatures and water stress. Eur J Agron. 2002;16: 112.

[44] Stepien A, Wojtkowiak K. Composition of gluten proteins in spring and winter wheat grains cultivated under conditions of varied fertilization. Acta Agric Scand, Section B - Soil \& Plant Science. 2013; 63 (7):588-594. DOI: 10.1080/09064710.2013.829866.

[45] Wieser H, Zimmermann G. Importance of the amounts and proportions of high molecular weight subunits of glutenin for wheat quality. Eur Food Res Technol. 2000; 210: 324-330.

[46] Singh J, Skerritt JH. Chromosomal control of albumins and globulins in wheat grain assessed using different fractionation procedures. J Cereal Sci. 2001; 33: 163-181. doi.org/10.1006/ jcrs.2000.0351

[47] Tóth B, Bilion A, Labuschagne M. Infuence of low soil nitrogen and phosphoruson gluten polymericand monomericprtein disributionin two high quality spring wheat cultivars. I Cereal Sci. 2020; 92: 1-6. doi.org/10.1016/j.jcs.2019.102867.

[48] Geisslitz S, Longin CFH, Scherf KA, Koehler P. Comparative Study on Gluten Protein Composition of Ancient (Einkorn, Emmer and Spelt) and Modern Wheat Species (Durum and Common Wheat). Foods. 2019 ; 8(9): 409. doi: 10.3390/ foods 8090409 